\title{
Zjištování účinnosti akčního programu podle nitrátové směrnice 91/676/EHS $v$ době klimatické změny
}

\author{
ANNA HRABÁNKOVÁ \\ Klíčová slova: zranitelné oblasti - dusičnany - akční program - nitrátová směrnice - klimatická změna
}

\section{SOUHRN}

Nitrátová směrnice definuje pravidla pro vymezení zranitelných oblastí a stanovuje nástroje ke snižení znečištění vod dusičnany ze zemědělské produkce. Základním nástrojem je akční program a také zásady správné zemědělské praxe [1]. Plnění zásad správné zemědělské praxe a akčního programu je ve zranitelných oblastech pro zemědělské podnikatele povinné. Účelné nastavení těchto pravidel pak nejenže umožní snížit stávající znečištění dusičnany, ale pomůže takovému znečištění i předcházet. Proto je nezbytné propojení detailního monitoringu zemědělského hospodaření a monitoringu vod, které nám dá nové poznatky o vzájemném ovlivňování hospodaření a kvality vod v různých klimatických a prírodních podmínkách [2]. V současnosti probíhá detailní monitoring akčního programu na 10 pilotních lokalitách v rámci celé České republiky.

\section{ÚVOD}

Cílem směrnice Rady 91/676/EHS o ochraně vod před znečištěním způsobeným dusičnany ze zemědělských zdrojů [3] (dále nitrátová směrnice) je snižovat znečištění vod, které pochází ze zemědělských zdrojů, a predcházet dalšímu takovému znečištování, a to jednak pro zajištění dodávek kvalitní pitné vody a jednak k ochraně povrchové vody před eutrofizací. V současné době jsou vyhlášeny zranitelné oblasti nařizením vlády č. 262/2012 Sb., o stanovení zranitelných oblastí a akčním programu, v platném znění [4], které nahradilo pưvodní nařízení vlády č. 103/2003 Sb. Součástí tohoto nařízení je i akční program, což je nastavený program opatření, která mají za cíl snížit znečištění vod dusičnany ze zemědělství prostřednictvím konkrétních postupů.

$\checkmark$ podmínkách České republiky je vyhlášen pouze jeden akční program, který je platný pro všechny vymezené zranitelné oblasti. Jednotlivá opatření akčního programu jsou však variantní a jejich uplatnění v zemědělské praxi se řídí půdně klimatickými podmínkami, vyskytujícími se na jednotlivých zemědělských pozemcích. Hlavní postupy uplatněné v akčním programu zahrnují podmínky používání hnojiv, skladování hnojiv a podmínky pěstování plodin. I přes výše uvedená opatření nedochází v některých vymezených zranitelných oblastech ke snižení znečištění povrchových i podzemních vod dusičnany a je třeba zaměřit pozornost na důvody, proč tomu tak je.

Podle nitrátové směrnice o ochraně vod před znečištěním způsobeným dusičnany ze zemědělských zdrojů, článku 5, odstavce 6 jsou členské státy povinny zavést monitorovací programy pro sledování účinnosti akčního programu. $\vee$ České republice jsou dosud aktivity související se sledováním

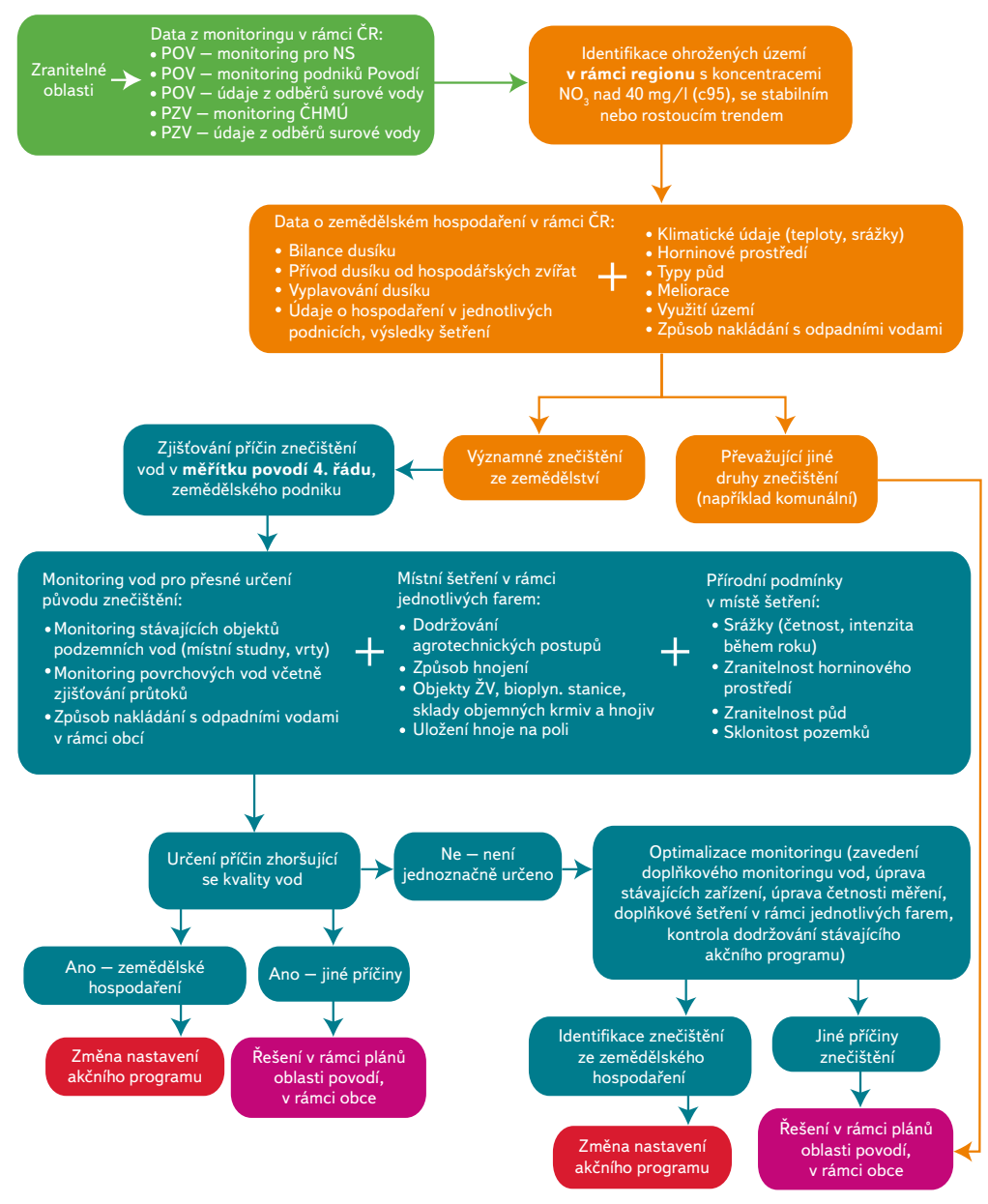

Obr. 1. Schéma postupu detailního zjištování účinnosti akčního programu Fig. 1. Scheme of the detailed evaluation of the Action Program effectiveness

účinnosti akčního programu vázány téměř výhradně na monitorování vybraných pilotních farem, kde jsou velmi podrobně hodnoceny agrotechnické postupy a vybrané kritické operace $[5,6]$. Vedle toho jsou pilotně $v$ povodí Želivky sledovány efekty zemědělského hospodaření na stav povrchových vod ve vybraných profilech na drobných zemědělských tocích. V rámci současného 
monitoringu jsou sledovány také dalši indikátory účinnosti akčního programu např. bilance dusíku, přeměna a pohyb dusíku $v$ půdě při různých způsobech hospodaření a v různých půdně-klimatických podmínkách.

Hlavním cílem prací pro zjištění príčin pokračujícího znečištění vod je však umožnit užší propojení stávajícího monitoringu zemědělského hospodaření ve zranitelných oblastech $\mathrm{s}$ monitoringem kvality vod. K tomuto účelu byla vytvořena v roce 2014 nová metodika detailního zjištování účinnosti akčního programu, zejména v oblastech se zvýšenými koncentracemi dusičnanů $\checkmark$ povrchových a podzemních vodách. Navržená metodika byla následně ověřena na čtyřech vytipovaných pilotních lokalitách v různých půdně-klimatických podmínkách a způsobech hospodaření. Byla vytvořena pravidla a pracovní postupy, které umožní detailní zjištování a vyhodnocení hlavních zdrojů znečištění vod v konkrétních oblastech a stanovení příčiny zhoršující se kvality vod. Výsledky monitoringu byly využity k upřesňování jednotlivých opatření akčního programu, k optimalizaci monitoringu vod a k vytváření podkladů pro jednání s Evropskou komisí. Potvrdil se předpoklad, že je potřeba postupovat od poznatků na úrovni ČR, popř. většího regionu, a zpřesňovat závěry pomocí podrobnějších šetření a monitoringu až do úrovně farem a malých povodí. Je to z toho důvodu, že některá dostupná data jsou k dispozici pouze v celostátním měřítku (napríklad údaje za kraje nebo okresy) a není možné je prímo vztahovat ke konkrétním mikropovodím nebo farmám. Po takto provedených analýzách $\checkmark$ širokém měřitku Ize postupovat k menším oblastem, ve kterých jsou k dispozici zase údaje př́slušející pouze konkrétním místům. Na obr. 1 je uvedeno výsledné schéma postupu detailního zjištování účinnosti akčního programu. Navržený postup predpokládá tři úrovně hodnocení. V celostátním měřítku (zelená barva), v měřítku regionu, popř. povodí 3. řádu (oranžová barva), a nakonec podrobné hodnocení v rámci malých povodí nebo farem (modrá barva). Na základě provedených kroků bude na konci celého procesu zjištěna příčina znečištění vod dusičnany a budou provedena opatření: nejprve optimalizace monitorovacích programů a $v$ prípadě prokazatelných skutečností pak následné kroky - opatření v rámci plánů oblastí povodí, vyřešení nakládání $s$ odpadními vodami a $\vee$ prípadě zemědělského znečištění bude provedena úprava akčního programu (změna způsobu hospodaření v těchto lokalitách).

\section{MONITORING ÚČINNOSTI AKČNÍHO PROGRAMU}

Tuto činnost Ize rozdělit do dvou hlavních kategorií, které v sobě zahrnují zemědělský monitoring a zjištování jakosti povrchových a podzemních vod.

\section{Zemědělský monitoring}

Sledování účinnosti akčního programu nitrátové směrnice v České republice je zajištěno $v$ rámci monitoringu akčního programu. Na monitoringu se pod koordinací Výzkumného ústavu rostlinné výroby, v. v. i., (VÚRV, v. v. i.) [7] podílí pracovníci Výzkumného ústavu zemědělské techniky, v. v. i., (VúZT, v. v. i.) a Výzkumného ústavu vodohospodářského T. G. Masaryka, v. v. i. (Vúv TGM, v. v. i.).

Monitoring akčního programu [8] mimo jiné zahrnuje:

- ověřovací průzkum plnění požadavků akčního programu v zemědělských podnicích ve zranitelných oblastech (cca 30-40 pilotních podniků),

- hodnocení vývoje obsahu půdního dusíku z hlediska pěstovaných plodin, používané agrotechniky a průběhu povětrnosti,

- terénní šetření $v$ zemědělských podnicích ve zranitelných oblastech (cca 200 podnikü),

- sledování vlivu hospodaření podle akčního programu na jakost vod v pilotním území zranitelných oblastí,
- hodnocení vlivu zemědělského hospodaření, půdně-klimatických podmínek a průběhu povětrnosti na jakost vod ve sledovaných měrných profilech a v 360 dílicích povodích ČR,

— zjištování toků dusíku ve zranitelných oblastech a modelování pohybu dusíku v půdě a vodě pro predpověd" budoucího vývoje jakosti vody,

- sledování vývoje způsobu hospodaření ve zranitelných oblastech na základě dat Českého statistického úradu, Evidence půdy podle uživatelských vztahů a Evidence hospodářských zviŕrat.

Při šetření na farmě jsou zjištovány tyto údaje:

A. základní informace o podnicích (identifikace podniku, celková obhospodařovaná půda, půda ve zranitelných oblastech, orná půda, trvalé travní porosty a celková výměra pastvy);

B. objekty živočišné výroby (stáje, sklady statkových a organických hnojiv, sklady konzervovaných krmiv, sklady sena, sklady slámy);

C. zimoviště a pastva (souřadnice zimoviště, typ zimoviště, druh, kategorie zviřat na zimoviště, počet zviŕat na zimovišti, počet dnů strávených na pastvě, počet hodin, které tráví zviŕata ve stáji ve dnech pastvy);

D. polní složiště hnoje (souřadnice složiště, objem složiště, plocha složiště);

E. obrat statkových hnojiv (výdej (prodej) statkových hnojiv mimo podnik, objem statkových hnojiv zpracovaných separací, kompostováním, v bioplynové stanici, likvidace statkových hnojiv ve smyslu zákona o odpadech);

F. rostlinná výroba a hospodaření na půdě (výnosy plodin, hnojení statkovými, organickými a minerálními hnojivy k jednotlivým plodinám, agrotechnická opatření).

\section{Monitoring povrchových a podzemních vod}

Pro vyhodnocení obsahu dusičnanů v povrchových vodách jsou využívány výsledky monitoringu pro potřeby nitrátové směrnice (dřive monitoring ZVHS), který v současné době provozují podniky Povodí, s. p. Jedná se o měření jakosti na malých tocích, kde lze predpokládat možný zemědělský zdroj znečištění. Tyto údaje jsou ještě doplňovány výsledky provozního monitoringu podniků Povodí, s. p., a dále údaji z rozborů jakosti povrchové surové vody určené pro lidskou spotřebu, vykazovaných podle vyhlášky č. 428/2001 Sb., o vodovodech a kanalizacích [9]. Údaje o jakosti podzemních vod jsou získávány z monitoringu ČHMú, který zahrnuje ve zranitelných oblastech 234 vrtů a 60 pramenů. Tyto údaje jsou doplňovány výsledky měření jakosti podzemní surové vody, které představují, vzhledem k jejich počtu a územnímu rozložení, zásadní zdroj informací o jakosti podzemní vody určené pro pitné účely, na což je kladen velký důraz v nitrátové směrnici. Celkem leží ve zranitelných oblastech téměř tisíc míst určených pro tyto odběry.

Pro vyhodnocení jakosti vody jsou velmi zásadní informací nejen průměrné a maximální hodnoty, ale predevším trendy vývoje koncentrací dusičnanů v jednotlivých místech. Proto při posuzování účinnosti akčního programu je pozornost zaměřena tímto směrem. Podkladem pro výběr pilotních povodí byly datové sady, ze kterých se vycházelo pro 3. revize zranitelných oblastí v roce 2015, tedy data do roku 2013 (surová voda) a 2014, nová data o surové vodě podle vyhlášky č. 428/2001 od té doby již nebyla vyhodnocována. Nejprve byla určena povodí 4. rádu, ve kterých se vyskytovaly koncentrace dusičnanů ve vodách nad $50 \mathrm{mg} / \mathrm{l}$, a současně byla provedena analýza polohy zemědělských podniků s kontinuálním sledováním (obr. 2). Vzhledem k tomu, že bylo cílem postihnout aktuální stav jednotlivých povodí, byla tato území rozdělena ještě do dalších tří kategorií z hlediska 


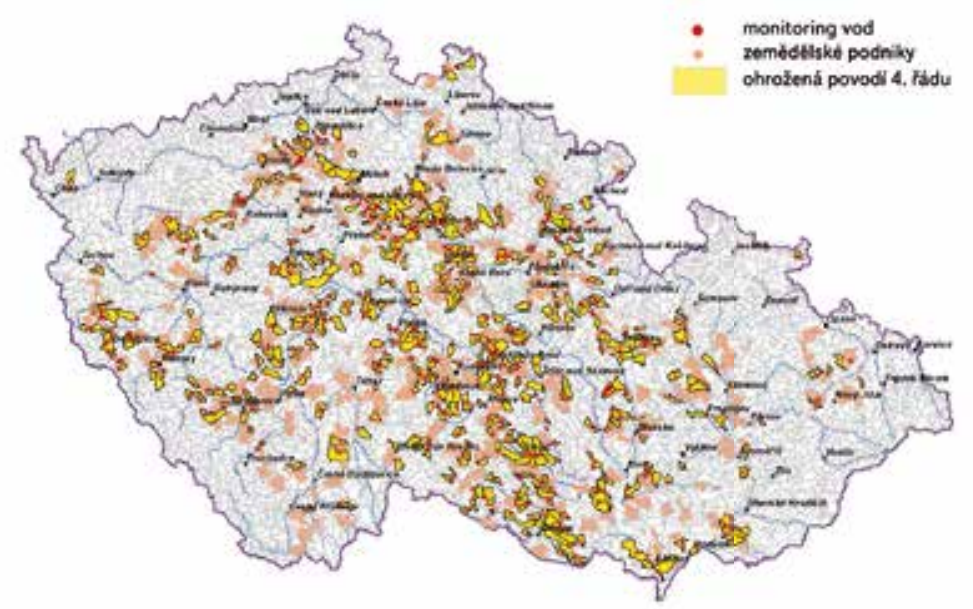

Obr. 2. Hydrologická povodí 4. rádu ve zranitelných oblastech s koncentracemi dusičnanů nad 50 mg/l a s kontinuálním sledováním zemědělských podniků Fig. 2. Hydrological catchments of $4^{\text {th }}$ order in vulnerable areas with concentrations of nitrates above $50 \mathrm{mg} / \mathrm{l}$ and with permanent monitoring of agriculture producers

vyhodnocení trendu vývoje koncentrace dusičnanů a také výskytu maximálních hodnot (obr. 3). V první kategorii tak byla povodí s klesajícím a stabilním trendem, druhou kategorii tvořila povodí s rostoucím trendem, ale s maximy do roku 2010, a nejohroženější třetí kategorie byla s výskytem stoupajících trendů a s maximy v období 2011-2013. Z těchto povodí pak byla vybrána potenciální pilotní povodí, ve kterých bylo plánováno prozkoumat funkčnosti nastavení akčního programu.

\section{POSOUZENÍ PŘÍRODNÍCH A KLIMATICKÝCH PODMIINEK}

Při konečném rozhodování o výběru pilotních území byly vzaty $v$ úvahu př́rodní a klimatické podmínky, které v sobě zahrnovaly:

— vodní bilanci, jejiž výpočet vycházel z potenciální evapotranspirace a gridové vrstvy průměrných srážkových úhrnů a teplot za období 1981-2010,

- retenční vodní kapacita půd,

— základní odtok s využitím mapy odtoku podzemní vody od Krásného a kol. [10],

- R-faktor - faktor erozní účinnosti deště s využitím databáze erozivních událostí.

Hodnocení v rámci celého území České republiky bylo založeno na výpočtu takzvaného Z-indexu, kde podle jeho hodnoty jsou území rozdělena do jednotlivých kategorií od výborného stavu až po extrémně zranitelná území.

\section{PILOTNÍ ÚZEMÍ PRO MONITORING AKČNÍHO PROGRAMU}

Podle již výše zmíněných kritérií bylo nakonec vybráno deset pilotních území (obr. 4) - hydrologických povodí 4. řádu, která leží ve zranitelných oblastech podle nitrátové směrnice. $V$ každém povodí probíhá alespoň částečný pravidelný monitoring povrchových nebo podzemních vod, který je nyní cíleně doplněn o nová monitorovací místa. Výběr těchto míst byl zaměřen na možné zemědělské znečištění, tedy na to, aby jednotlivé odběry nebyly ovlivněny napríklad komunálním vypouštěním apod. Monitoring s průběžným vyhodnocováním bude probíhat minimálně čtyři roky, vždy v jarním a podzimním období, které je kritické pro vyplavování dusičnanů do povrchových i mělkých podzemních vod. V průběhu výzkumu bude současně kromě monitoringu vod a zemědělského hospodaření posouzen vliv klimatické změny. První výsledky monitoringu akčního programu budou již na konci roku 2018.

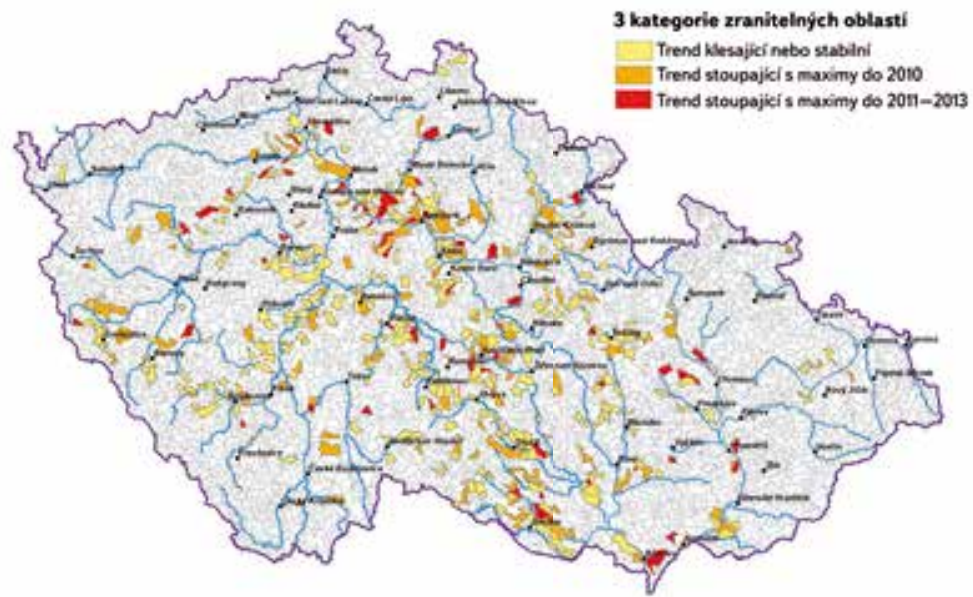

Obr. 3. Ohrožená hydrologická povodí 4. rádu ve zranitelných oblastech rozdělená do tří kategorií

Fig. 3. Threatened hydrological catchments of $4^{\text {th }}$ order in vulnerable areas divided into 3 categories

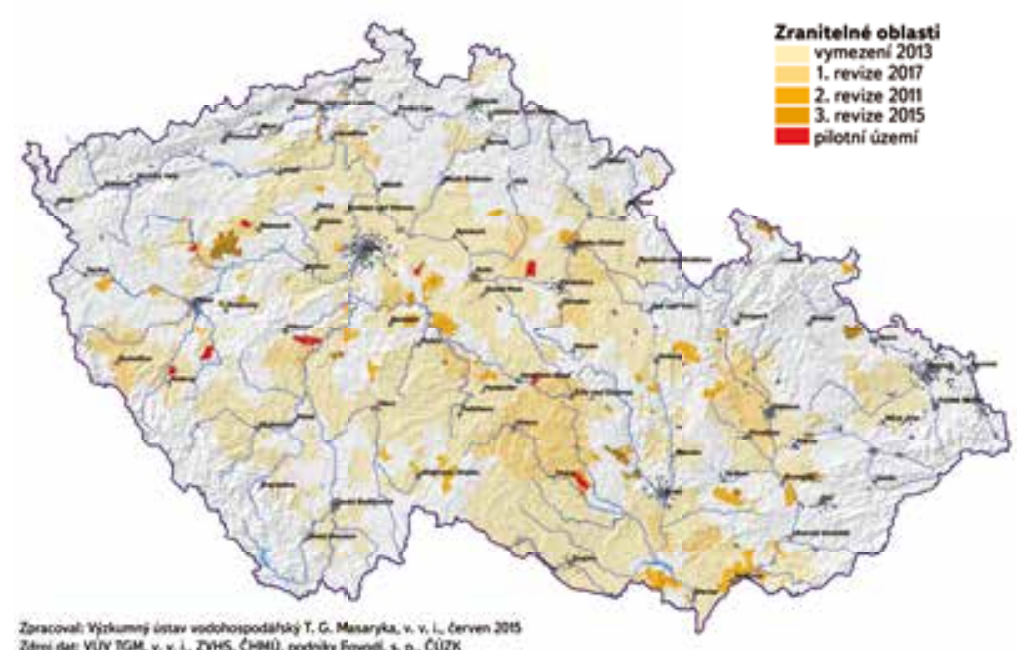

Obr. 4. Pilotní území ve zranitelných oblastech

Fig. 4. Pilot areas in vulnerable areas

\section{VÝSLEDKY A DISKUSE}

Hlavním cílem zjištování účinnosti akčního programu je cílený proces pro zajištění zlepšení jakosti povrchových i podzemních vod vhodnou volbou zemědělského hospodaření v konkrétních místech s respektováním specifických přírodních podmínek tak, jak to požaduje evropská i naše legislativa. Ukazuje se, že právě klimatické podmínky, častý výskyt suchých období a změna celoročního cyklu srážek i teplot nabývá stále větší důležitosti. Z této skutečnosti také vyplynul výběr 10 pilotních území, kde v současné době probíhá detailní monitoring vod a zemědělského hospodaření až do podrobnosti jednotlivých půdních bloků. Povodí 4. rádu byla vybrána v různých klimatických regionech a s různými prírodními podmínkami, aby bylo možné získané poznatky v budoucnu využít i pro podobná území. Výsledky budou sloužit již pro revize zranitelných oblastí v roce 2019 a pro přípravu revize akčního programu. Průběžné výsledky budou publikovány na specializovaném webu provozovaném VÚRV, v. v. i. [8]. 


\section{Poděkování}

Přispěvek vznikl na základě dlouhodobé činnosti podporované Ministerstvem životního prostředí a Ministerstvem zemědělství.

\section{Literatura}

[1] KLÍR, J. a KOZLOVSKÁ, L. Zásady hospodařeni pro ochranu vod před znečištěním dusičnany. Metodika pro praxi. Praha: VÚRV, v. v. i., 2016.

[2] HRABÁNKOVÁ, A. a kol. Hodnocení účinnosti akčního programu formou detailního monitoringu dopadu implementace nitrátové směrnice na kvalitu vod 2015 - Zranitelnost přrrodního prostředí z hlediska možnosti šřreni dusičnanového znečištěni do podzemních a povrchových vod. Praha: VúV TGM, v. v. i., 2015.

[3] CEC Council Directive of 12 December 1991 concerning the protection of waters against pollution caused by nitrates from agricultural sources, 91/676/EEC. Official Journal No L 375, 31. 12. 1991, p. 1.

[4] Nařízení vlády č. 262/2012, ze dne 4. července 2012, o stanovení zranitelných oblastí a akčním programu.

[5] KLÍR, J. a kol. Inovace systémů zemědělského hospodařeni v prostředi kvartérnich sedimentů, jejich overéení a aplikace v ochranných pásmech vodních zdrojů QJ1320213, 2013-2017. Praha: VÚRV, v. v. i.

[6] KLÍR, J. a kol. Šetření v zemědělských podnicích 2013 - 232-2013-14131. Praha: VÚRV, v. v. i., 2013.

[7] KLÍR, J. a kol. Metodický návod pro hospodaření ve zranitelných oblastech. 2. aktualizované vydání. Certifikovaná metodika pro praxi. Praha: VÚRV, v. v. i., 2018.

[8] Dostupné z: www.nitrat.cz

[9] Vyhláška č. 428/2001 Sb., ze dne 16. listopadu 2001, kterou se provádí zákon o vodovodech a kanalizacích pro veřejnou potřebu a o změně některých zákonů (zákon o vodovodech a kanalizacích).

[10] KRÁSNÝ, J., DAŇKOVÁ, H., HANZEL, V., KNĚŽEKE, M., MATUŠKA, M. a ŠUBA, J. Mapa odtoku podzemn vody ČSSR 1. Praha: Český hydrometeorol. úst. Kartografie, 1981

\section{Autor}

Ing. Anna Hrabánková

凶anna.hrabankova@vuv.cz

Výzkumný ústav vodohospodářský T. G. Masaryka, v. v. i.

Příspěvek prošel lektorským řízením.

\section{DETERMINING OF EFFECTIVENESS \\ OF THE ACTION PROGRAM ACCORD- ING TO THE NITRATE DIRECTIVE IN A PERIOD OF CLIMATE CHANGE}

\section{HRABANKOVA, A.}

TGM Water Research Institute, p. r. i.

Keywords: vulnerable zones - nitrate action programme - Nitrates Directive

The Nitrate Directive defines rules for a delimitation of vulnerable zones and sets out tools to reduce nitrate pollution. The fundamental instrument is the Action Program and the Good Agricultural Practices [1]. The execution of the Good Agricultural Practices and the Action Program is mandatory in vulnerable areas for agricultural entrepreneurs. Efficient setting of these rules will not only allow the reduction of existing nitrate pollution but will also help to prevent such pollution. Therefore, it is necessary to link the thorough monitoring of agricultural management and water monitoring, which will give us new insights into the interaction between agriculture and water management in different climatic and natural conditions [2]. Currently, a detailed monitoring of the Action Program was introduced in 10 pilot catchments within the entire Czech Republic. 